\title{
Paradigm of Early Childhood Art's Education
}

\author{
Indra Yeni \\ Department of Early Childhood Education \\ Universitas Negeri Padang, Indonesia \\ indrayeni.30031971@gmail.com
}

\author{
Alriska Hairi Dilfa \\ Department of Early Childhood Education \\ Universitas Negeri Padang, Indonesia \\ alriska.hd@gmail.com
}

\begin{abstract}
One of the government policies in the education sector is the implementation of Early Childhood Education (ECE). Art in ECE is an important role in demanding attention for all parties and understanding and more efforts especially for education practitioners. Over time the shift in the role of making art in education has a dual paradigm. The purpose of writing is to express the paradigm of art education that has a dual role behind government policy. This article is a conceptual article, problem analysis with literature search. The results of the theoretical discussion show that there are two artistic roles in early childhood education in the present. First, art as a medium to be able to develop aspects of physical motor development, social-emotional, religious and moral, cognitive, and language. Second, art is an attempt to develop art itself.
\end{abstract}

Keywords: arts, children and, early childhood education's institution

\section{INTRODUCTION}

Education is an effort to channel knowledge and values that apply in society by educators to students. This is in accordance with the Law of National Education Article 1 paragraph 1 which explains that education is a conscious and planned effort to create a learning atmosphere and learning process so that students actively develop their potential to have religious spiritual strength, self-control, personality, intelligence, noble character and skills needed by him, society, nation and state. Besides that education is an effort to foster the development and potential of individual abilities that are deliberately and planned so that they are useful for the benefit of their lives both as individuals and in community members.

One of the government policies in the education sector is the implementation of Early Childhood Education (ECE). Early childhood education is a very basic and strategic education in the development of human resources. Early childhood education is essentially education that is organized with the aim of facilitating the growth and development of children as a whole or emphasizing the development of all aspects of the child's personality. Therefore, ECE provides an opportunity for children to develop their personalities and potential to the maximum. On this basis, ECE institutions need to provide various activities that can develop various aspects of development.

In accordance with Law of National Education No. 20 of 2003 concerning the national education system which states that so-called early childhood are children aged 0 to 6 years. As written in Law No. 20 of 2003 concerning Article 28 of the National Education System which explains that ECE is organized through 3 channels, namely: First, formal education paths in the form of Kindergarten, Raudatul Athfal (RA) (kind of Islamic Kindergarten) or other forms of equal; Second, nonformal education channels in the form of Playgroups, Child Care Centers or other equivalent forms and thirdly, informal education channels take the form of family education. Kindergarten is a place for learning while playing, playing while learning and learning while playing. The learning system seems to be different from at school, kindergarten learning is integrated by containing several programs that are considered to trigger child development, and art is an important program in early childhood.

Behind the government's policy of art's education in early childhood education has overlapping nature, Art was once eliminated in the ECE Institution's curriculum and after that art was returned to ECE Institution's curriculum. In the past, the 2009 Goverment's policy says that Art was eliminated because art had inserted into other learning, and in Permendikbud 2014 Art was returned again in ECE Institution's curriculum. So that make anxiety for academics and early childhood education practitioners. It comes to our mind, how can art be returned in ECE Institution's curriculum. Of course because art is considered important. So, there are two dual concepts in learning physical-motoric, social emotional, religious and moral, cognitive, and language in children and can support art lessons that can control cognitive learning through art.

In the general sense of art education is a conscious effort to prepare students through coaching, learning and training activities so that students have artistic abilities. The ability of art in terms of its objectives can be divided into two. First, art education is directed so that students have competencies related to the artistic or textual actors. Then art education is directed so that students have artistic competence as a form of learning experience in order to mature the potential of individuals so that they can become "whole people" (contextual) [1] . The opinion reinforced Ros's concept of inheritance in Jazuli [1] that art education is a medium to inherit or transmit the ability of art as a manifestation of cultural transformation from generation to generation carried out by artists. Then in its development the process of art education began to be institutionalized both formal and informal.

Rohidi, [2] states that art education interprets physical, intellectual and creativity abilities and links education, culture and art in a more dynamic and meaningful way. Then According to Ki Hajar Dewantara, art is the result of beauty so that it can move the beautiful feelings of those who see it, therefore human actions that can influence can create a beautiful feeling that art. There is a variety of arts education in Indonesia, namely art, 
dance, and music. Art has an important role as a basic need for human education, fulfilling basic aesthetic needs, developing attitudes and personality, and a determinant of other intelligences.

Art education is expected to be able to foster and develop creativity and sensitivity, support the formation and development of a whole person. Providing the widest opportunity for creative expression. The vision of art education needs to lead to: 1). Understanding of the role of art in human life that is civilized and cultured; 2 ). The ability to assess and meaningful artistic experiences in the context of cultural life; 3). Improve competencies to explore, uncover, and communicate ideas, views and feelings through the media of art; 4). Provide aesthetic considerations in personal and group capacity. Art programs in education have an important meaning not only expanding the mind but keeping children out of the way and out of the correctional system.

The mission of art education is to educate and teach students through art media within the framework of 1). Developing attitudes, knowledge and skills in the field of art (music, dance, visual) to fulfill basic aesthetic needs and prepare students for further education; 2). Increase awareness and sensory sensitivity; 3 ). Give freedom to creative expression; 4). Grow and develop selfconfidence, responsibility in shared life; 5). Building togetherness in difference, cultural plurality (FBS Team UNNES, 2001). Art education is an understanding of aesthetics (beauty) and aesthetic re-expression in a work of art. Understanding aesthetics is an event that incorporates aesthetics through sensing the feeling and thought of objectifying, while the second is how art can learn something else, which in this case art is considered as a medium of education. Meanwhile, according to Soetedja, [3] stated that the goals of art education include: 1) Self-fulfillment; 2) Understanding artistic heritage; and 3) and understand the role of art in society. All three work together in two paradigms of art education, namely intricate and extracurricular elements.

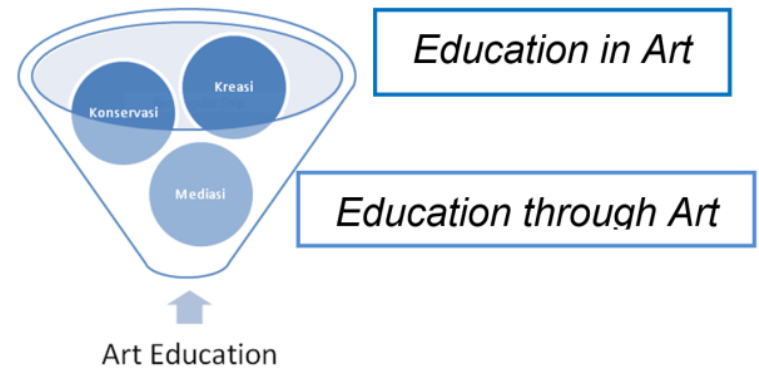

Figure 1

The Three Roles of Art Education

Then it can be concluded essentially axiologically that art education is in the middle (balance) between science. In the opinion of the author there are three roles of art education including: 1) The function of conservation, is to instill values and appreciation of culture; 2) Creative functions make students have the creative will to work so that they have artistic creatures and actualized aesthetic experiences; 3) Mediation Function, art education can be used as a tool to explain other knowledge, such as in ECE institutions children learn to recognize letters and numbers through singing which can be summarized in the Figure 1.

If it is associated with the concept of the dual role of art education "the first about the benefits of art that is expected to be a dual role of art can be utilized according to Soeharjo [4] as commonly called 'learning with art' and 'learning through art' namely the concept of Education in Art (learning through art) and Education through Art (learning with art). In the present, this is often a confusion of understanding, especially for early childhood education practitioners. However, the problem with many assumptions that assume that art in early childhood is enough as just another learning media such as Respati's opinion [5] "A more appropriate paradigm in looking at music art education can be straightened out with refidenition again".

Therefore the author considers the need for a review of conceptual articles regarding the dual paradigm of early childhood art education behind the government's policy on aspects of art in the standard of ECE implementation.

\section{EARLY CHILDREN ARTS EDUCATION PARADIGM}

Early age is the most appropriate time to build and develop all potentials starting from language, cognitive, religious moral values, social and emotional. One potential that needs to be developed early in the child is insight and sense of art. Art is one of the basic potentials of children and also one form of plural intelligence. Respati [5] Expressing the benefits of learning music for children is to shape humans through art in the sense of developing human potential to become fully human.

Developing children's artistic potential also means developing their intelligence. If this potential is not developed early on, the golden period of developing this potential will pass. Therefore, ECE teachers who act as facilitators in developing the potential of the arts are equipped with insights about the arts in children so that teachers can carry out their roles well. Without sufficient provision, the teacher will not be able to develop children's artistic potential optimally. Art education in children is directed to the formation of attitudes so that there is intellectual balance, and sensibility, rational and irrational, mind and emotional sensitivity, make skilled human beings physically and mentally, motor, cognitive, psychomotor abilities develop well and optimally. In accordance with Permendikbud (Goverment's policy) No.137 of 2014 the Arts have the ability to explore and express themselves, imagine the movement of music, art, and various other fields of art and are able to appreciate works of art, movement and dance, and drama. While the standard level of achievement of early childhood development for the art field is divided based on the stages of age.

There are two roles of art education, namely the concept of art as a medium of "education through art" that is like children learning to count through songs and secondly, the concept of "education in art" children learn art in their own pure art. 


\section{A. Learning Paradigm Through Art}

Learning Through Art or known as the concept of Education through art education through art or art education has important roles and functions for education in general. In other words, in an educational perspective, art is seen as a tool or means to achieve educational goals. The approach to education through art was also put forward by J. Dewey that art should be a tool to achieve educational goals rather than for the sake of art itself. With this approach art education is obliged to help achieve educational goals in general that provide rational balance and emotional, intellectual and sensibility. In other words the approach to art education is not placed in efforts to develop and preserve art.

Therefore the paradigm of approach through art must be instilled and taught from an early age. Education through art basically uses art as a medium or a tool to achieve educational goals, so in its implementation the emphasis is on the aspect of the process rather than the results. The emphasis in terms of the process of making the target of learning art education does not expect students to be good at drawing, painting, or sculpting. Therefore the approach to education through art in the implementation of learning emphasizes that there is exploration and experimentation, stimulating curiosity and at the same time pleasing to children. There is a variety of arts education in Indonesia, namely art, dance, and the art of music all developed according to the development stage and in accordance with aspects of its development.

Answering the case above why art was abolished means not not at all because art is considered something that overlaps in the daily activities of children in its learning environment, but some research and opinions prove that singing is done to support other aspects of the lesson.

One of the main activities for early childhood art education is singing, singing has an important role for children. Teaching music if managed properly will be able to provide many benefits in increasing students' creativity. In the Big Indonesian Dictionary (KBBI) singing is sounding pitched; work while reducing fatigue. As in kindergarten that singing is a vehicle for learning while playing. Through singing children can learn many things. Kamtini and Tanjung [6] "Singing is a means of expressing thoughts and feelings, because singing activities are important for the education of children besides singing is a fun activity that gives satisfaction to children". According to Somad A.W, et al. [7] Singing as a medium for delivering messages / da'wah. This is reinforced by the statement Purwadi [8] he concluded that singing can be used as one of the effective learning methods because of the simple and pleasant way. Supported by the opinion of Yeni [9] about the role of music in kindergarten "Through music and singing can channel, control, cause certain feelings such as feeling happy and funny".

Widihanawati [10] states that motion and song learning can affect and control nerve centers so that it helps children to further develop their intelligence. Both cognitive intelligence, emotional language to physical and motoric. Yeni [11] suggests that music embodies a sense of togetherness and belonging so that it can improve social skills.

Art with children cannot be separated as well as education, according to opinion [2] Early childhood education can be seen for example through singing. For example by singing to know religion, learning to count, and so forth. According to Fatur [12] states that singing part of music serves as a tool to devote thoughts and feelings to communication. Apart from the art of music (singing) as well as other arts as in Aprillia [13] the basic purpose and function of art education is to shape the child's personality. Personal formation means having freedom and democracy factors thinking, creating and acting positively.

So to answer the government's policy on Permendikbud 2009 which had eliminated aspects of art, but arts such as singing activities were still held in institutions such as kindergarten. In moving, singing or dancing activities, it can be concluded that art is a medium to be able to develop aspects of physical motoric, social-emotional, religious and moral, cognitive, and language development in children. Therefore, the development of the purpose of the role of art should be able to support aspects of social emotional, motoric, cognitive, religious and moral development, as well as language in early childhood based on that understanding. Art is expected to develop children's creativity, and provide the widest opportunity for expression.

\section{B. Paradigm of Learning with Art}

The second role is to learn with art, that is, children learn art itself only puppets are only giving aesthetic experiences in art activities such as when children learn through music and know sounds. This is in accordance with government policy on Permendikbud No.137 of 2014, Art has the ability to explore and express themselves, imagine the movement of music, drama, and various other fields of art (painting, fine arts, crafts) and able to appreciate works of art, motion and dance, and drama. While the standard level of achievement of early childhood development for the art field is divided based on the stages of age.

In education, the field of educational research develops and practices that inform inquiry into learning through artistic experience. In this context, art can include (dance, drama, music), literature and poetry. This is distinguished from art education with not so much about the art of teaching, but focuses on: increasing learning through art, transferring learning through other disciplines, discovering and creating understanding of human behavior, thinking, potential, and learning especially through close observation of work art and various forms of involvement in artistic experience. Agreeing with Rahmawati [14] the purpose of art education is to foster children's potential to support the growth of creativity and growth that is created when the child's psychological freedom is maintained by telling stories and playing which are children's habits.

Art programs give children a place to express themselves to do it at home, and can also make children think creatively and attentively, broadening children's thinking in general. Petty [15] states that art is a means of 
fulfilling individual interests for the expression of personal development, in line with Maslow's opinion in Ryckman [16] which states that, the need for expression exists in children. This concept is also in line with the expression theory concluded by Sahman [17] stating that, "art can be formulated as an activity of expressing or channeling the feelings and forms of expression for children is' the symbol of the drawing, jumping, moving, dancing and singing ".

In accordance with the discussion on the subject, the teacher should increase the power and attention to the art aspect itself while for art as an educational medium but with the help of digital art-based learning media that can facilitate teachers such as Dilfa et al. [18] that bookbased singing media Digital songs that are developed are feasible, practical, and can be a tool in the singing process. Then it must also be supported by the mastery of art material maximally for teachers, through increasing teacher competence, because these two paradigms are equally important and must be balanced.

\section{CONCLUSION}

The art for early childhood education has a very important influence and a positive impact on children's growth and development. In addition to giving an output to the achievement of the aspects of art itself, it also plays an important role in other fields such as language, communication, physical, emotional, cognitive, knowledge, social and aesthetic.

The results of the theoretical discussion show that there are two artistic roles in early childhood education. First, art as a medium to be able to develop aspects of physical motor development, social-emotional, religious and moral, cognitive, and language in early childhood. Then the second, art as an aspect of education is given to improve the ability to explore and express themselves, imagine the movement of music, drama, and various other fields of art (painting, fine arts, crafts) and able to appreciate works of art, movement and dance, and drama which is developed in accordance with the stages of the child's age.

It can be concluded that there are two roles in learning arts, namely, education in art (learning in art) and education through art (learning through art). We need to realize that art education in the realm of early childhood education mas now has a dual paradigm, for that efforts more optimal approach to early childhood education.

\section{REFERENCES}

[1]. Jazuli, Muhammad. 2008. Paradigma Kontekstual Pendidian Seni. Semarang: Unnes University press.

[2]. Rohidi, Tjetjep Rohendi. 2014. Pendidikan Seni Isu Dan Paradigma. Semarang: Cipta Prima Nusantara.

[3]. Soetedja Z. S. 2007. Ilmu Dan Aplikasi Pendidikan. Bandung: Pedagogiana Press.

[4]. Soeharjo, A. J. 2012. Pendidikan Seni: Dari Konsep Sampai Program. Malang: Bayu Media Publising.

[5]. Respati Reza. 2015. "Esensi Pendidikan Seni Musik Untuk Anak.” Saung Guru VII No 2.

[6]. Kamtini dan Tanjung. 2005. Bermain Melalui Gerak Dan Lagu Di Taman Kanak-Kanak. Jakarta: DIRJEN DIKTI.

[7]. Somad Abdul Wahid Dkk. 2006. Fiqh Entertaimen. Surabaya: Diantama.

[8]. Purwadi. 2013. "Pembelajaran Melalui Bernyanyi Untuk Menstimulasi Sikap Dan Perilaku Musikal Anak Pada Pusat Unggulan PAUD Taman Belia Candi Semarang." catharsis Vol.2 No.1.

[9]. Yeni, Indra. Pengantar Seni Musik Untuk Pendidikan Anak Usia Dini. Padang: Sukabina Press

[10]. Widihanawati Nana. 2011. "Pengaruh Pembelajaran Gerak Dan Lagu Dalam Meningkatkan Kecerdasan Musikal Dan Kecerdasan Kinestetik Anak Usia Dini.” jurnal.upi.edu edisi khus.

[11]. Yeni, Indra. 2017. Pelatihan Mencipta Lagu Anak Pada Guru PAUD di Kecamatan ABTB Kota Bukittinggi dan Kecamatan Tilatang Kamang Kab. Agam. PEDAGOGI : Jurnal Anak Usia Dini dan Pendidikan Anak Usia Dini

[12]. Fatur Rasyid. 2010. Cerdaskan Anakmu Dengan Musik. Yogyakarta: Diva Press.

[13]. Aprillia. 2014. "Konsepsi Pendidikan Seni Rupa Di Taman Kanak." Imajinasi Vol. VIII.

[14]. Rahmawati. 2004. Mencetak Anak Cerdas Dan Kreatif. Kumpulan Artikel. Jakarta: Penerbit Buku Kompas.

[15]. Petty, W.T. Ed. 1976. Curriculum for the Modern Elementary School. Chicago: Rand Mc Nally College Publishing Compa.

[16]. Ryckman, R.M. 1985. Theories of Personality. California: Books Cole Publishing Company Monterey.

[17]. Sahman. 1993. Mengenali Dunia Seni Rupa: Tentang Seni, Karya Seni, Aktivitas Kreatif, Apresiasi, Kritik Dan Estetika. Semarang: IKIP Semarang Press.

[18]. Dilfa, A.H dkk. 2018. "Buku Lagu Digital Anak Untuk Taman Kanak-Kanak: Studi Pengembangan Media Audivisual." e-jurnal sendratasik, unp 6,No.2 